\title{
DIVERSIFIKASI PANGAN MELALUI SISTEM USAHA TANI AGROFORESTRI DI KABUPATEN BOALEMO
}

\author{
Ulfiasih $^{1}$, Merita Ayu Indrianti ${ }^{2}$, \\ ${ }^{1}$ Program Studi Agribisnis, Fakultas Ilmu-Ilmu Pertanian Universitas Muhammadiyah \\ Gorontalo, J1 Prof. Dr. H. Mansoer Pateda Desa Pentadio Timur Kabupaten Gorontalo, \\ Ulfiasihagb@yahoo.com, ayu_sutarto@yhaoo.co.id \\ Email Korespendensi: ayu_sutarto@yahoo.co.id
}

\begin{abstract}
ABSTRAK
Penelitian ini dilakukan di Kabupaten Boalemo pada Bulan April 2018 dengan tujuan untuk mengkaji upaya diversifikasi pangan melalui sistem usahatani agroforestri. Responden dalam penelitian ini adalah petani agroforestri. Data yang diperoleh merupakan data kualitatif. Data ini di analisis menggunakan analisis deskriptif. Hasil penelitian menunjukkan bahwa petani agroforestri sudah berupaya melakukan diversifikasi pangan dengan menanam jenis tanaman pangan selain padi dan jagung yaitu singkong dan kacang hijau meskipun belum diusahakan secara komersial.
\end{abstract}

Kata Kunci: Pangan, Usahatani, Agroforestri, Boalemo 


\section{PENDAHULUAN}

Indonesia merupakan negara yang mengalami peningkatan jumlah penduduk cukup besar, sehingga kebutuhan pangan masyarakat juga harus ditingkatkan. Namun krisis ekonomi yang terjadi bersamaan dengan penurunan produksi pangan yang terjadi akibat perubahan iklim telah mengakibatkan penurunan dan keterbatasan persediaan pangan masyarakat. Hal ini semakin diperparah dengan semakin menurunnya minat petani untuk menanam tanaman pangan khususnya padi diakibatkan oleh meningkatnya harga bibit, pupuk dan lain-lain.

Agroforestry dikembangkan untuk memberi manfaat kepada manusia untuk meningkatkan diversifikasi dalam ketahanan pangan masyarakat. Pada penerapan sistem agroforestry Rahayu dan Aghestine (2013) berpendapat bahwa, agroforestry diharapkan dapat membantu mengoptimalkan hasil suatu bentuk penggunaan lahan secara berkelanjutan guna menjamin dan memperbaiki kebutuhan bahan pangan. Pencapaian sasaran peningkatan diversifikasi produksi pangan dapat dilakukan dengan pola intensifikasi melalui peningkatan pemanfaatan lahan hutan dengan sistem agroforestry.

Salah satu cara yang dapat ditempuh adalah pengelolaan hutan rakyat dengan menerapkan model pengusahaan lahan hutan sekunder dan pemberdayaan masyarakat lokal melalui sistem agroforestri. Sistem ini merupakan salah satu model pengusahaan hutan rakyat dengan memadukan komponen tanaman kehutanan dengan komponen tanaman pertanian. Menurut Simon (1994), pembangunan kehutanan merupakan bagian dari pembangunan ekonomi nasional atau regional. Di pedesaan peranan kehutanan sangat menonjol karena dapat menyediakan lapangan pekerjaan yang sesuai dengan ketrampilan penduduk setempat dan menyediakan bahan baku untuk berbagai macam industri. Secara umum tujuan pembangunan ekonomi adalah meningkatkan kesejahteraan masyarakat.

Selain komponen tanaman kehutanan yang ditanam dan dihasilkan pada lahan agroforestri, komponen tanaman pertanian juga banyak ditanam dan dihasilkan pada lahan tersebut.Hal ini menunjukkan bahwa selain menguntungkan dari segi lingkungan, sistem agroforestri juga menguntungkan dari segi ekonomi.Melalui penanaman komponen tanaman pertanian, hasil yang di peroleh dapat dipergunakan untuk memenuhi kebutuhan sehari-hari maupun untuk dijual sehingga dapat dijadikan sumber pendapatan ekonomi keluarga.

Ketahanan pangan sangat penting untuk diwujudkan, hal ini berkaitan dengan pemenuhan kebutuhan pangan masyarakat dari waktu ke waktu baik kuantitas maupun kualitasnya.

\section{METODE PENELITIAN}

\section{Lokasi dan Waktu Penelitian}

Penelitian ini dilakukan di Kabupaten Boalemo, Provinsi Gorontalo. Penelitian ini dilaksanakan pada bulan April 2018.

\section{Teknik Pengambilan Data}

Data yang dikumpulkan adalah data primer dan data sekunder. Data primer mencakup informasi tentang tanaman pangan yang diusahakan petani agroforestri. Data primer diperoleh langsung melalui wawancara kepada petani agroforestri, sedangkan data sekunder diperoleh melalui dari instansi/lembaga terkait seperti Badan Pusat Statistik Kabupaten Boalemo, Kantor Camat dan Kantor Desa serta studi literatur dari penelitian sebelumnya.

\section{Populasi dan Teknik Penarikan Sampel}

Populasi dalam penelitian ini adalah petani lahan kering di Kabupaten Boalemo. Petani yang dipilih adalah petani yang telah menerapkan sistem agroforestri dalam teknik usahataninya. Populasi dalam penelitian ini berjumlah 75 petani agroforestri.

Teknik penarikan sampel yang digunakan adalah metode sampel jenuh (Saturation Sampling). Jumlah populasi dalam penelitian ini adalah 75 petani. Untuk mengetahui keberagaman jenis tanaman pangan yang diusahakan petani, maka seluruh 
populasi petani agroforestri di Kabupaten Boalemo digunakan sebagai sampel.

\section{Teknik Analisis Data}

Analisis data yang digunakan adalah analisis deskripsi. Melalui analisis deskripsi peneliti mampu menggambarkan realita upaya diversifikasi pangan berdasarkan jenisjenis tanaman pangan yang diusahakan petani agroforestri.

\section{HASIL DAN PEMBAHASAN}

\section{Jenis Tanaman Pangan yang diusahakan} Petani

Jagung merupakan tanaman pangan yang banyak diusahakan petani. bahkan selama dua tahun terakhir sebagian besar petani belum melakukan pergiliran tanaman pangan selain jagung secara komersial. Usahatani jagung dilakukan secara tumpang sari dan/atau agroforestri. Sebagian besar petani mengusahakan beberapa tanaman pangan selain jagung hanya di pekarangan rumah dengan tujuan konsumsi (Tabel 1).

Tabel 1. Jenis tanaman pangan yang diusahakan petani

\begin{tabular}{|l|c|c|}
\hline \multirow{2}{*}{$\begin{array}{c}\text { Kelompok } \\
\text { Pangan }\end{array}$} & \multicolumn{2}{c|}{ Peruntukan } \\
\cline { 2 - 3 } & Komersial & $\begin{array}{c}\text { Konsumsi } \\
\text { Keluarga }\end{array}$ \\
\hline Jagung & $\checkmark$ & $\checkmark$ \\
\hline Singkong & & $\checkmark$ \\
\hline Kacang Hijau & & $\checkmark$ \\
\hline
\end{tabular}

Sumber: Olahan Data primer (2018)

Pada Tabel 1 mengindikasikan bahwa petani sudah berupaya melakukan penganekaragaman jenis tanaman pangan meskipun tidak diusahakan secara komersial. Singkong merupakan tanaman pangan yang paling banyak dikonsumsi keluarga petani sebagai substitusi beras setelah jagung. Diversifikasi pangan juga mempengaruhi diversifikasi konsumsi pangan. Sebagian besar petani juga menuturkan adanya manfaat dengan melakukan diversifikasi konsumsi pangan diantaranya adalah manfaat kesehatan yakni mengurangi kadar gula(glukosa) dalam tubuh. Menurut Sukesi dan Shinta (2011), diversifikasi konsumsi pangan memiliki peranan yang sangat penting dalam upaya untuk meningkatan perbaikan gizi serta untuk mendapatkan manusia yang berkualitas.

\section{Diversifikasi Pangan melalui Sistem Agroforestri}

Agroforestri dikenal dengan sistem usahatani yang terdiri atas lebih dari satu jenis tanaman dalam satu luasan lahan. Oleh sebab itu, upaya diversifikasi pangan melalui sistem agroforestri sangat memungkinkan untuk dilakukan. Senada dengan yang dikatakan oleh Sitepu (2014), agroforestri merupakan salah satu sistem pengelolaan lahan yang mungkin dapat ditawarkan untuk mengatasi masalah yang timbul akibat adanya alih-guna lahan dan sekaligus juga mengatasi masalah pangan.

Berdasarkan hasil penelitian, terdapat petani yang menanam tanaman pangan selain jagung. Usaha penanaman tanaman pangan seperti singkong dan kacang hijau ini dilakukan dilahan terpisah (monokultur). Beberapa alasan petani tidak melakukan pergiliran tanaman selain jagung untuk diusahakan secara komersial antara lain; 1) sulitnya proses pemeliharaan dan perawatan tanaman; 2) sulit menjangkau akses pasar; 3) kurang diminati petani dan konsumen; 4) kebiasaan petani membudidayakan jagung. Kusumedi dan Jariyah (2010), menambahkan alasan petani jarang melakukan pergiliran tanaman dikarenakan pemilihan jenis tanaman pada lahan agroforestri sebagian besar karena turun temurun. Kebanyakan petani kurang untuk mengadopsi jenistanaman agroforestri dari lain tempat bahkan masih berpikiran tradisional dalammemadukan pola agroforestrinya tanpa melakukan teknik silvikultur mulai dari penanamansampai dengan pengaturan hasil sehingga sangat tergantung dari masingmasing manajemen rumah tangga petani.

Sebagian besar lahan di Kabupaten Boalemo memiliki topografi berbukit sehingga mudah terjadi erosi apabila usahatani hanya dilakukan secara monokultur saja. Oleh sebab itu, agroforestri dapat dijadikan sebagai alternatif solusi mengurangi dampak dari pada erosi untuk melakukan diversifikasi pangan dengan kombinasi tanaman tahunan (pohon). 
Keberadaan pohon dalam agroforestri mempunyai dua peranan utama; 1) pohon dapat mempertahankan produksi tanaman pangan dan memberikan pengaruh positif pada lingkungan fisik, terutama dengan memperlambat kehilangan hara dan energi, dan menahan daya perusak air dan angin; 2) hasil dari pohon memiliki peran penting dalam perekonomian rumah tangga petani. Pohon dapat menghasilkan produk yang digunakan langsung seperti bahan bakar, bahan bangunan dan input untuk pertanian seperti pakan ternak, mulsa serta produk atau kegiatan yang mampu menyediakan lapangan kerja atau penghasilan kepada anggota rumah tangga dalam jangka panjang (Hairiah et al., 2003).

Selain tanaman jagung, masih ada jenis tanaman pangan yang bisa diusahakan untuk melakukan pergiliran, misalnya kacang tanah, singkong, ubi jalar dan lain sebagainya. Menurut De Foresta (2000) dalam Mayrowani dan Ashari (2011), mengatakan bahwa jenis pangan dari hutan yang banyak dikembangkan antara lain padi, jagung, kacang-kacangan, dan umbi-umbian.

Tanaman kacang-kacangan dikenal sebagai tanaman leguminosa. Keuntungan mengkombinasikan tanaman leguminosa dengan tanaman lainnya adalah mampu mengikat nitrogen dari dalam tanah, sehingga kebutuhan unsur hara $\mathrm{N}$ tidak selalu berasal dari pupuk melainkan sebagian disuplai dari tanaman leguminosa. Menurut Suparwata dan Ulfiasih (2017), bahwa pemilihan jenis menjadi salah satu hal yang harus

\section{DAFTAR PUSTAKA}

Hairiah, K., M.A Sardjono., dan S. Sabarnurdin.2003. Pengantar Agroforestri. World Agroforesty Centre (ICRAF) Southeast Asia Regional Office. Bogor.

Kusumedi, P., dan N.A Jariyah. 2010. Analisis Finansial Pengelolaan Agroforestri dengan Pola Sengon Kapulaga Di Desa Tirip, Kecamatan Wadaslintang, Kabupaten Wonosobo. JurnalPenelitian Sosial diperhatikan dalam pengaturan vegetasi agroforestri termasuk jenis tanaman palawija (kacang-kacangan) seperti kacang hijau dan kacang tanah. Selain kacangkacangan, singkong juga dapat dijadikan sebagai pangan umbi-umbian yang diusahakan secara komersial. Singkong bisa ditanam secara random (acak) bisa juga sebagai tanaman sela diantara pohon kelapa atau pohon jabon.

Usaha diversifikasi pangan dapat diwujudkan apabila petani mengetahui pentingnya pemilihan jenis vegetasi termasuk karakteristik vegetasi dan potensi tanaman itu sendiri, juga pola tanam agroforestri. Tujuannya adalah untuk memperoleh hasil yang optimal dari masing-masing tanaman. Apabila upaya diversifikasi pangan telah dilakukan maka keluarga petani tidak akan cenderung mengkonsumsi satu jenis pangan.

\section{PENUTUP}

Kabupaten Boalemo sudah melakukan upaya diversifikasi pangan dengan menanam dan mengkonsumsi pangan selain beras dan jagung seperti singkong dan kacang hijau meskipun belum diusahakan secara komersial.

Saran yang dapat diberikan adalah hendaknya pemerintah melakukan lembaga terkait dapat meneruskan bimbingan atau pendampingan secara continue kepada petani agroforestri dan diperlukan penyuluhan dan pendampingan tentang pentingnya pemilihan jenis dalam melakukan usahatani agroforestri terutama tanaman pangan untuk mewujudkan diversifikasi pangan.

dan Ekonomi Kehutanan, 7 (2): 93100 .

Mayrowani, H., dan Ashari. 2011. Pengembangan Agroforestri untuk Mendukung Ketahanan Pangan dan Pemberdayaan Petani Sekitar Hutan. Forum Penelitian Agro Ekonomi, 29(2): 83-98.

Simon, H., 1994. Merencanakan Pembangunan Untuk Strategi Kehutanan Sosial. Yayasan Pusat 
Studi Sumberdaya Hutan. Yogyakarta.

Sitepu, Y.F. 2014. Kontribusi Pengelolaan Agroforestri Terhadap Pendapatan Rumah Tangga Petani (Studi Kasus Di Desa Sukaluyu, Kecamatan Nanggung, Kabupaten Bogor, Jawa Barat). Skripsi. Institut Pertanian Bogor. Bogor.

Sukesi, K., dan A. Shinta. 2011.Diversifikasi Pangan Sebagai Salah Satu Strategi Peningkatan Gizi Berkualitas Di
Kota Probolinggo (Studi Kasus di Kecamatan Kanigaran). Jurnal SEPA, 7(2): 85-90.

Suparwata, D.O., dan Ulfiasih. 2017. Konservasi dan Keberlanjutan Pertanian: Suatu Kajian Metode Penerapan KTA oleh Petani Pedesaan. Prosiding Seminar Nasional Pertanian. Wiratani dalam Agribisnis Indonesia: Fakta Harapan dan Tantangan. Universitas Muhammadiyah Makassar. 